\title{
SURVIVAL IN MEN DIAGNOSED WITH PROSTATE CANCER IN POLAND IN YEARS 2000 - 2014 COMPARED TO EUROPEAN COUNTRIES BASED ON CONCORD-3
}

\author{
Aleksandra Gliniewicz ${ }^{I}$, Dorota Dudek-Godeaul, Magdalena Bielska-Lasotal \\ ${ }^{1}$ National Institute of Public Health - National Institute of Hygiene, \\ Department of Economic and Systems Analyses, Warsaw, Poland
}

\begin{abstract}
Background. Wealthy countries have observed in recent decades a fast-growing number of prostate patients, who require treatment and long-term cancer care. This trend seems to be connected with some demographic changes such as aging societies, better access to diagnostic methods with high sensitivity as well as large-scale secondary prevention (prostate cancer screening at early stage before clinical manifestation). Secondary prevention is becoming more accessible and widely applied. The expected effect of prevention is to improve overall survival while the mortality trend is decreasing. The prevention success requires highly effective healthcare system that must manage additional burden which is a consequence of the need to provide optimal treatment and healthcare in a big group of cancer patients diagnosed in effective prevention programms. According to the National Cancer Registry (NCR) the number of incidence from year 1980 - 1731 cases rose in year 2013 to 12162 cases. Apart from incidence and mortality rates, the 5-year survival is a significant factor for the assessment of a population healthcare and healthcare system efficiency. The prognosis related to prostate incidence is 22344 men in year 2025 in comparison to 12162 in year 2013 - that would be a double rise in incidence. CONCORD-2 results (years 1995-2009) showed, among the others, that cancer curability for some cancers, including prostate cancer improved. In year 2018 the results of CONCORD-3 were published (years 2000-2014) showing a rising trend in improvement in prostate cancer curability in Poland

Objective. The objective was to analyse the 5-year survival in prostate cancer patients in Poland, and in each of 16 voivodships, with the focus on changes in years 2000 - 2014 in comparison to European trends.

Material and Methods. The analysis was based on the 5-year net survival (estimated in CONCORD-3) in prostate cancer patients diagnosed in Poland (NCR national data) and in all Polish voivodships.

The 5-year survival of prostate cancer patients and its changes in years 2000 - 2014 compared between 16 voivodships, Poland in total and 28 European countries.

Results. In Poland in years 2010 - 2014 the 5-year survival in prostate cancer patients was $78.1 \%$, and compared to years 2000 - 2004 rose by 9.3 percentage points. Despite a systematic improvement in survival the differences between individual voivodships in Poland remained. In 6 voivodships the survival was higher than average for Poland and ranged from 80 to $82 \%$. The lowest survival was in Opolskie voivodship - 72.3\%. On a European scale, the curability of prostate cancer at that time was over $90 \%$ (9 countries), while Poland was among 5 countries whose total survival rate was less than $80 \%$ (from $72.3 \%$ - Opolskie voivodship to $83.6 \%$-- Pomeranian voivodship).

Conclusions. The 5-year survival in prostate cancer patients in years $2010-2014$ in Poland was significantly lower in comparison to Western Europe countries, and favourable trends on a regional level in Poland were too slow to overcome high differentiation in Europe. It is expected that changing the structure and organisation of cancer care in Poland into a modern National Oncology Network Comprehensive Cancer Care Network, together with the use of the experiences from European projects, including iPAAC and better financing will contribute to improvement in prostate cancer treatment in Poland.
\end{abstract}

Key words: prostate cancer, curability, mortality trend, cancer care, CONCORD-3

\section{STRESZCZENIE}

Wprowadzenie. Wskutek starzenia się społeczeństwa, a także w wyniku postępu medycyny i wprowadzenia na szeroką skalę programów profilaktycznych liczba chorych na choroby nowotworowe wymagających leczenia i opieki w ostatnich latach szybko wzrasta - wykrywane jest więcej zmian nowotworowych o wczesnym stopniu zaawansowania wymagających dalszej diagnostyki. Profilaktyka wtórna staje się coraz łatwiej dostępna i szeroko stosowana. Oczekiwanym efektem profilaktyki jest poprawa przeżyć ogółem przy równoczesnym obniżającym się trendzie umieralności. Niezbędnym warunkiem sukcesu profilaktyki jest wysoka sprawność systemu lecznictwa, który musi podołać dodatkowemu

Corresponding author: Aleksandra Gliniewicz, National Institute of Public Health - National Institute of Hygiene, Department of Economic and Systems Analyses, 24 Chocimska Str, 00-791 Warsaw, Poland, tel. +48 225421331, e-mail: agliniewicz@pzh.gov.pl

(C) Copyright by the National Institute of Public Health - National Institute of Hygiene 
obciążeniu wynikającemu z potrzeby zapewnienia optymalnego leczenia i opieki dużej grupie chorych z rakiem wykrytym w skutecznych działaniach profilaktycznych. Prognozy Krajowego Rejestru Nowotworów (KRN) dotyczące zachorowań na raka prostaty przewidują, że w roku 2025 roku zachoruje 22344 mężczyzn ; w porównaniu do 12 162 w roku 2013 - byłby to prawie dwukrotny wzrost zachorowań. Oprócz zachorowalności i umieralności istotnym elementem oceny stanu zdrowia społeczeństwa oraz skuteczności systemu opieki zdrowotnej jest wskaźnik 5-letnich przeżyć. Wyniki CONCORD-2 (obejmujące lata 1995 - 2009) wykazały m.in., że w Polsce wyleczalność na niektóre nowotwory, w tym i na raka gruczołu krokowego poprawiła się. W 2018 roku zostały opublikowane wyniki trzeciej edycji projektu, obejmujące lata 2000 - 2014, które wskazują na utrzymywanie się trendu poprawy wyleczalności nowotworu gruczołu krokowego w Polsce.

Cel. Analiza wskaźnika 5-letnich przeżyć chorych na raka gruczołu krokowego w latach 2000 - 2014 w Polsce, w tym w 16 województwach, ze szczególnym uwzględnieniem zmian na tle trendów w krajach europejskich.

Material i metody. Badania oparto o wartości wskaźnika 5-letnich przeżyć (net survival) obliczone w projekcie CONCORD -3 oraz dane krajowe z Krajowego Rejestru Nowotworów (KRN). Wskaźnik 5-letnich przeżyć chorych na raka gruczołu krokowego a także jego zmiany, w latach 2000-2014, porównano między 16 województwami oraz w Polsce ogółem ze wskaźnikami 5-letnich przeżyć z 28 krajów europejskich.

Wyniki. W Polsce ogółem w latach 2010 - 2014 wskaźnik 5-letnich przeżyć chorych na raka prostaty wynosił 78.1\% i w porównaniu do lat 2000 - 2004 jego wartość wzrosła o 9.3 pkt\%. Pomimo systematycznej poprawy przeżyć utrzymywało się zróżnicowanie pomiędzy województwami w Polsce. W sześciu województwach wartość wskaźnika była wyższa niż w Polsce ogółem i wynosiła od 80 do $82 \%$. Najniższe przeżycia były w woj. opolskim: $72.3 \%$. W skali Europy wyleczalność raka gruczołu krokowego w tym okresie sięgała ponad 90\% (9 krajów) natomiast Polska była wśród 5 krajów, których przeżycia ogółem były niższe niż 80\% (od 72.3\% - woj. opolskie do 83.6\% - woj. pomorskie).

Wnioski. W Polsce wskaźnik 5-letnich przeżyć chorych na raka gruczołu krokowego w latach 2010 - 2014 był znacząco niższy w porównaniu z krajami Europy Zachodniej, a korzystne trendy na poziomie regionalnym w Polsce były zbyt wolne aby zniwelować znaczące zróżnicowanie w Europie. Oczekuje się, że przekształcenie struktury i organizacji lecznictwa onkologicznego w Polsce w nowoczesną Krajową Sieć Onkologiczną Szpitali, z wykorzystaniem doświadczeń $\mathrm{z}$ projektów europejskich, w tym iPAAC, wraz z wyższym poziomem finansowania przyczynią się do poprawy wyleczalności raka prostaty w Polsce.

Słowa kluczowe: rak prostaty, wyleczalność, trend umieralności, oncological treatment,CONCORD-3

\section{INTRODUCTION}

Wealthy countries have observed in recent decades a fast-growing number of prostate patients, who require treatment and long-term cancer care. This trend seems to be connected with some demographic changes such as aging societies, better access to diagnostic methods with high sensitivity as well as large-scale secondary prevention programmes (prostate cancer screening at early stage before clinical manifestation).

The prevention success requires proper healthcare financing and highly effective healthcare system that must manage additional burden which is a consequence of the need to provide optimal treatment and healthcare in a big group of cancer patients diagnosed in effective prevention programmes.

Since the late 90's the analysis of incidence and mortality trends have been conducted in Poland, and their results are systematically published in modern forms by the National Cancer Registry. According to the National Cancer Registry the number of incidence from year 1980 - 1731 cases rose in year 2013 to 12 162 cases [16].

Since the modern assessment of cancer control in Organisation for Economic Cooperation and Development (OECD) countries includes the 5-year net survival together with incidence and mortality rates, availability of data on cancer survival and the 5-year survival is particularly important [17].
Apart from incidence and mortality rates, the 5-year survival is a significant factor for the assessment of a population health and healthcare system efficiency. Data from National Registries must follow very strict CONCORD standards. Standardised methods of data collection and analysis in the CONCORD-study [4, 5 ] allows for comparison between the voivodships and monitoring of the survival rate changes over time.

The 5-year net survival and survival trends for patients worldwide were estimated and published in CONCORD-3 based on data on 37513025 patients from 5 continents [5].

CONCORD-3 obtained the population data from 16 voivodships in Poland from the National Cancer Registry. All data was processed in a systematic quality control within the CONCORD procedures, which allowed for correct conclusions based on time trends' analysis and comparisons between countries and regions.

CONCORD-2 results (years 1995-2009) showed, among the others, that cancer curability for some cancers, including prostate cancer improved [4]. In year 2018 the results of CONCORD-3 were published (years 2000-2014) [5] showing a rising trend in improvement in prostate cancer curability in Poland. 


\section{Objective}

The objective was to analyse the 5-year survival in prostate cancer patients in Poland, and in each of 16 voivodships, with the focus on changes in years 2000 - 2014 in comparison to European trends.

\section{MATERIAL AND METHODS}

The study compares the 5-year survival in male prostate cancer patients and its changes in years 2000 -2014 in 16 voivodships in Poland. The results are also discussed in comparison to other European countries.

The analysis was based on the 5-year net survival (estimated in CONCORD-3) in prostate cancer patients diagnosed in Poland (national data) and in all Polish voivodships. Incidence and quality data are presented in Table 1. Moreover, the 5-year survival for Poland, including individual voivodships was compared with the results from 28 European countries (Figure 2, Table 2).

Within CONCORD-3 study the 5-year survival was estimated based on data from national or regional registries in 322 administrative regions worldwide which met the criteria described by International Agency for Research on Cancer (IARC) [18], mainly in the scope of cancer completeness and detection.

Further systematic data quality control within CONCORD-3 covered the cancer follow-up and death time information if patients died during follow-up (till 31 December, 2014). Missing data was completed in the cooperation with cancer registries.

The survival analysis does not cover the cases lost from observation or with unconfirmed diagnosis of malignancy, unspecified morphological changes and follow-up shorter than 24 hours. The estimates and analysis of results were performed and published by one research centre - The London School of Hygiene

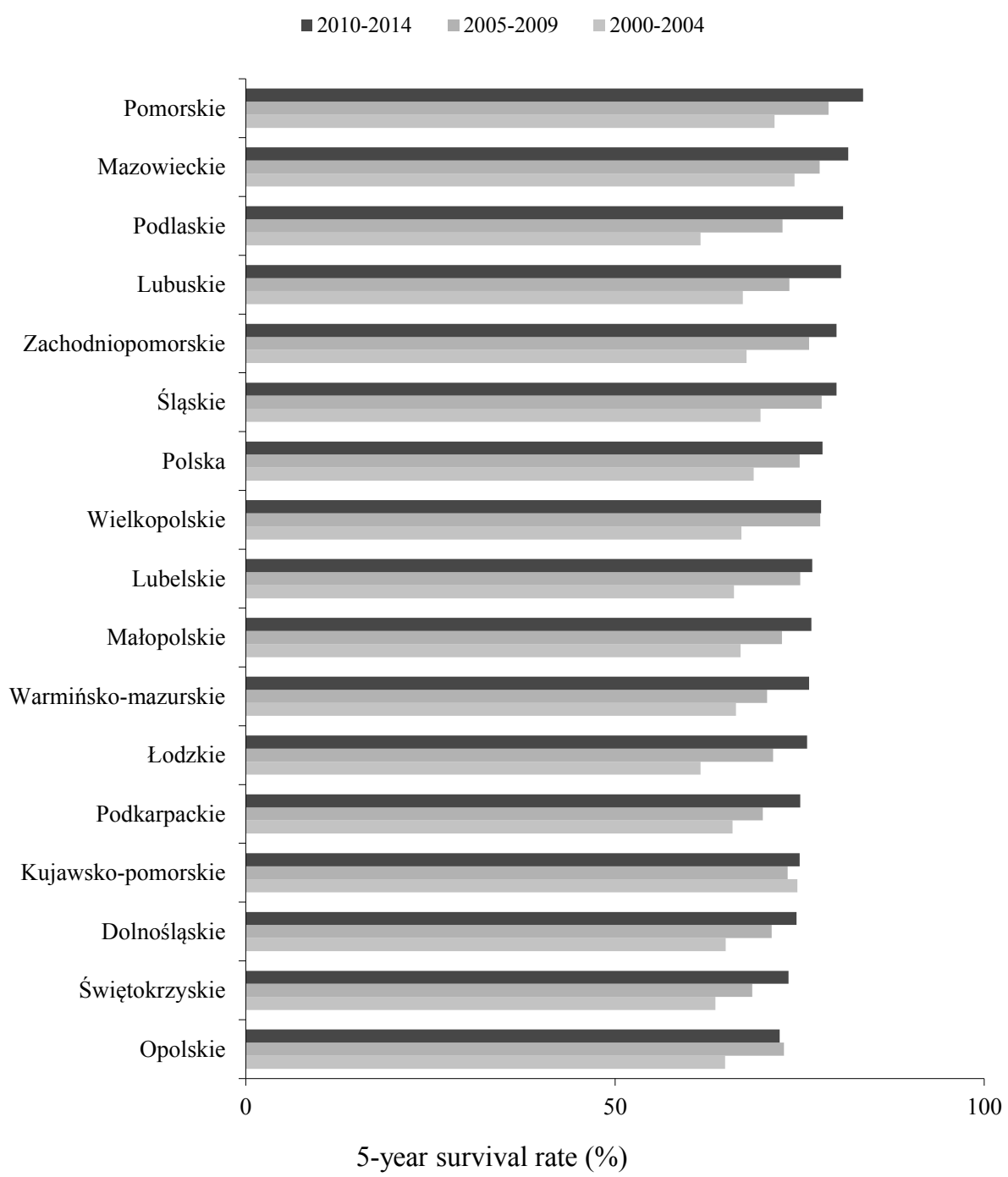

*Net survival

Figurel. Differentiation and changes in the 5-year survival rate* in patients diagnosed with prostate cancer in Poland and in 16 Polish voivodships in years $2000-2014$ 
Table 1. Number of cases, data quality and 5-year survival rate* of patients diagnosed in years 2000-2014 for prostate cancer and changes in survival rate in years 2000-2014 in Poland

\begin{tabular}{|c|c|c|c|c|c|c|}
\hline & $\begin{array}{l}\text { No of cases } \\
\text { included } \\
\text { into survival }\end{array}$ & $\begin{array}{l}\text { Excluded } \\
\quad(\%)\end{array}$ & $\begin{array}{c}\text { Verified } \\
\text { microscopically }\end{array}$ & 5-year s & val rate & $\begin{array}{l}\text { Absolute } \\
\text { difference }\end{array}$ \\
\hline & $2000-2014$ & & & $\begin{array}{c}2000-2004 \\
\mathrm{a} \\
\end{array}$ & $\begin{array}{c}2010-14 \\
b\end{array}$ & $\begin{array}{c}2000-14 \\
b-a\end{array}$ \\
\hline Polska & 131099 & 2.7 & 94.3 & 68.8 & 78.1 & 9.3 \\
\hline Dolnośląskie & 9248 & 0.6 & 84.8 & 65.8 & 73.4 & 7.6 \\
\hline ujawsko-pomorskie & 6951 & 1.1 & 98.3 & 74.7 & 75.0 & 0.3 \\
\hline Lubelskie & 7628 & 5.2 & 92.4 & 66.1 & 76.7 & 10.6 \\
\hline Lubuskie & 3056 & 1.9 & 97.3 & 57.3 & 80.6 & 23.3 \\
\hline Łódzkie & 7446 & 2.7 & 88.0 & 61.6 & 76.0 & 14.4 \\
\hline Małopolskie & 11487 & 3.4 & 95.3 & 67.0 & 76.6 & 9.6 \\
\hline Mazowieckie & 18407 & 0.1 & 94.6 & 74.3 & 81.6 & 7.3 \\
\hline Opolskie & 3061 & 0.3 & 98.6 & 64.9 & 72.3 & 7.4 \\
\hline Podkarpackie & 7572 & 3.8 & 98.6 & 65.9 & 75.1 & 9.2 \\
\hline Podlaskie & 3981 & 7.3 & 93.9 & 61.6 & 80.9 & 19.3 \\
\hline Pomorskie & 9379 & 6.0 & 98.5 & 71.6 & 83.6 & 12.0 \\
\hline Śląskie & 17032 & 0.8 & 93.8 & 69.7 & 80.0 & 10.3 \\
\hline Świętokrzyskie & 5200 & 2.3 & 94.2 & 63.6 & 73.5 & 9.9 \\
\hline Warmińsko-mazurskie & 4035 & 0.6 & 98.3 & 66.4 & 76.3 & 9.9 \\
\hline Wielkopolskie & 12004 & 5.0 & 97.5 & 67.1 & 77.9 & 10.8 \\
\hline Zachodniopomorskie & 4612 & 5.2 & 87.9 & 67.8 & 80.0 & 12.2 \\
\hline
\end{tabular}

*) Net survival

and Tropical Medicine, which guarantees uniformity of processes and results' interpretation.

Polish data was analysed and provided by the National Cancer Registry in the cooperation with Voivodship Cancer Registries which covered the registration of all 16 administrative regions in Poland.

The analysis for cancer curability and its changes in Poland and 16 Polish voivodships in comparison to selected European countries was evaluated based on the survival difference in years 2000-2004 and 2010 - 2014. Mortality trends from the National Cancer Registry and the overview of Polish healthcare condition were used to discuss the cancer burden in Poland.

\section{RESULTS}

Figure 1 shows the 5-year survivals in men diagnosed with prostate cancer in years $2000-$ 2004 and 2010 - 2014. In Poland in years $2000-$ 2004 the 5-year survival in prostate cancer patients was $68.8 \%$ (Figure 1, Table 1). The highest was in patients in Kujawsko-Pomorskie voivodship (74.7\%), Mazowieckie voivodship (74.3\%), Pomorskie voivodship (71.6\%) and Śląskie voivodship (69.7\%). In remaining 12 voivodships the 5-year survival was lower than the average survival for Poland (Figure
1, Table 1). The lowest survival was in Łódzkie and Podlaskie voivodships $-61.6 \%$.

In Poland in years 2010 - 2014 the 5-year survival in prostate cancer patients was $78.1 \%$, and compared to years $2000-2004$ rose by 9.3 percentage points. Despite a systematic improvement in survival the differences between individual voivodships in Poland remained. In 6 voivodships the survival was higher than average for Poland and ranged from 80 to $82 \%$. The lowest survival was in Opolskie voivodship $72.3 \%$.

Despite a systematic improvement in survival in Poland in years 2010 - 2014 compared to years 2000 - 2004 the prostate cancer curability was lower than in the majority of European countries. In 9 countries the survival was above $90 \%$, and only in 5 countries, including Poland, the survival was lower than $80 \%$ (Figure 2, Table 2).

As presented in Figure 2, differentiation in survival in years 2000 - 2004 in Europe was significant, and the 5-year survival rate ranged from $92.1 \%$ in Belgium to $49.4 \%$ in Bulgaria. In that period the 5-year survival between Polish voivodships ranged from 61.6 percentage points (Łódzkie and Podlaskie voivodships) to 74.7 percentage points (KujawskoPomorskie voivodship) - Figure 1. 


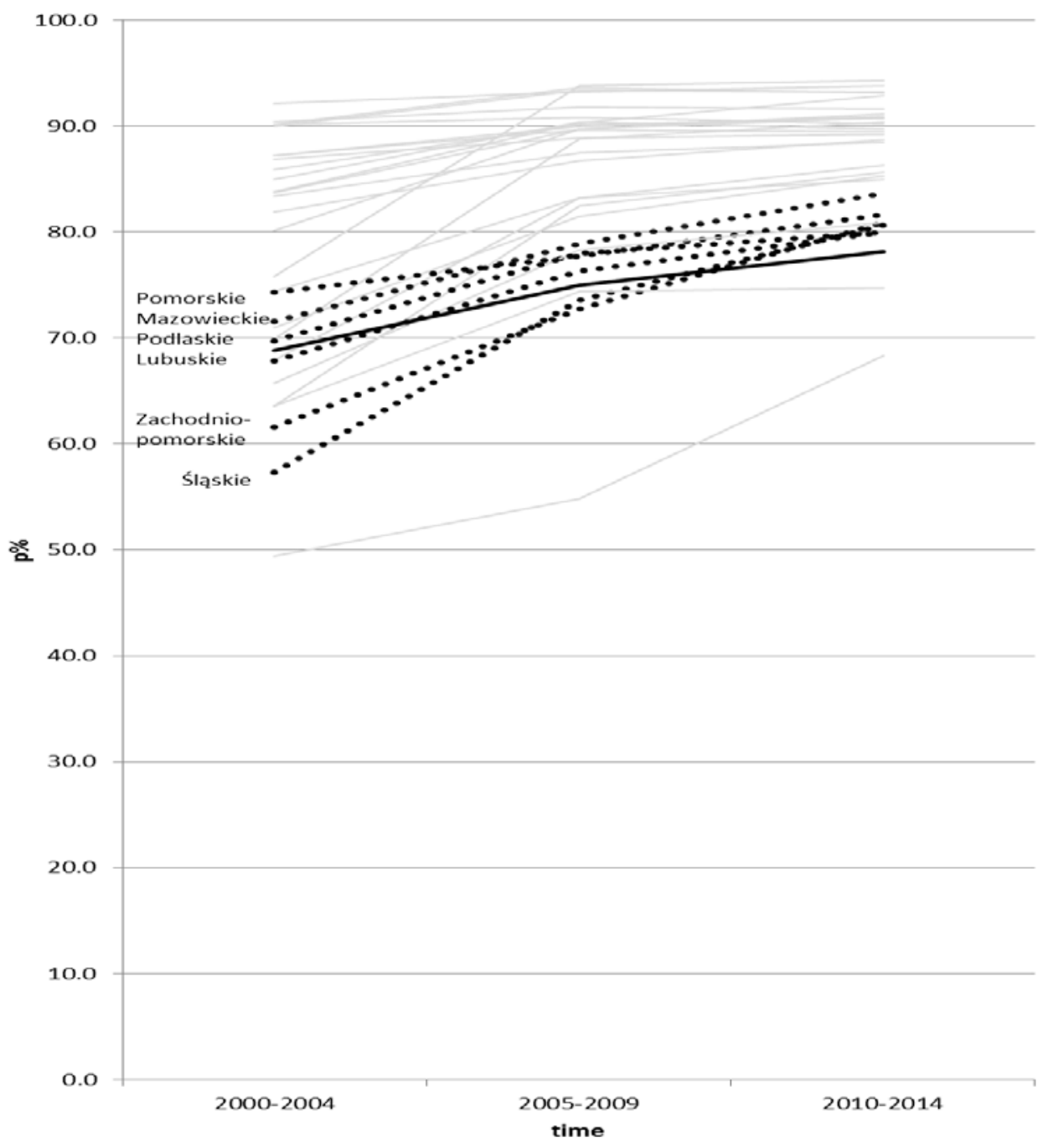

*Net survival,

** Dotted lines indicate voivodships with the survival rate above the country's average: Pomorskie, Mazowieckie, Podlaskie, Lubuskie, Zachodniopomorskie, Śląskie; black line - Poland (total); grey lines - European countries

Figure 2. The 5-year survival rate* in patients diagnosed with prostate cancer in Poland compared to European countries in years $2000-2014^{* *}$

Table 2. Number of cases, data quality and 5-year survival rate*) of patients diagnosed for prostate cancer in years 20002014 and changes in survival rate in European countries and several Polish voivodships in years 2000-2014. (Number of cases. Data quality).

\begin{tabular}{|c|c|c|c|c|c|c|}
\hline \multirow[t]{2}{*}{ Country } & \multirow{2}{*}{\begin{tabular}{|c|}
$\begin{array}{c}\text { No. of cases } \\
\text { included into } \\
\text { survival analysis }\end{array}$ \\
$2000-2014$ \\
\end{tabular}} & \multirow[t]{2}{*}{$\begin{array}{l}\text { Excluded } \\
(\%)\end{array}$} & \multirow[t]{2}{*}{$\begin{array}{c}\text { Verified } \\
\text { microscopically } \\
(\%)\end{array}$} & \multicolumn{2}{|c|}{$\begin{array}{c}5 \text {-year survival rate } \\
(\%)\end{array}$} & \multirow{2}{*}{$\begin{array}{c}\text { Absolute } \\
\text { difference } \\
\text { (pkt\%) }\end{array}$} \\
\hline & & & & $\begin{array}{c}2000-2004 \\
a\end{array}$ & $\begin{array}{c}2010-2014 \\
\text { b }\end{array}$ & \\
\hline Austria & 78087 & 3.3 & 98.9 & 90.1 & 90.8 & 0.7 \\
\hline Belgium & 100855 & 0 & 99.7 & 92.1 & 93.2 & 1.1 \\
\hline Bułgaria & 27814 & 5.8 & 92.5 & 49.4 & 54.8 & 5.4 \\
\hline Croatia & 23908 & 6.9 & 85.7 & 65.7 & 78.3 & 12.6 \\
\hline Czech R. & 22066 & 0.9 & 96.4 & 71.0 & 81.5 & 10.5 \\
\hline Denmark & 55055 & 0 & 98.3 & 63.6 & 82.5 & 18.9 \\
\hline Estonia ${ }^{1)}$ & 10139 & 4 & 94.4 & 67.9 & 83.2 & 15.3 \\
\hline Finland & 67.538 & 0 & 99.5 & 90.0 & 93.4 & 3.4 \\
\hline France & 92.614 & 0.6 & 99.6 & 90.1 & 93.6 & 3.5 \\
\hline
\end{tabular}




\begin{tabular}{|c|c|c|c|c|c|c|}
\hline Spain ${ }^{2)}$ & 65866 & 1.9 & 92.0 & 85 & 90.4 & 5.4 \\
\hline Netherlands & 144281 & 0.6 & 97.5 & 83.4 & 87.5 & 4.1 \\
\hline Ireland ${ }^{3)}$ & 38329 & 1.1 & 93.3 & 83.7 & 89.7 & 6 \\
\hline Lithuania $^{4)}$ & 30.954 & 2.5 & 94.6 & 75.8 & 93.8 & 18 \\
\hline Latvia & 13151 & 0.6 & 100.0 & 69.9 & 88.8 & 18.9 \\
\hline Malta ${ }^{5)}$ & 2130 & 2.6 & 94.3 & 81.9 & 86.4 & 4.5 \\
\hline Germany & 309196 & 7.4 & 98.9 & 90.4 & 91.8 & 1.4 \\
\hline Poland & 134755 & 2.7 & 94.3 & 68.8 & 75.0 & 6.2 \\
\hline Portugal & 66072 & 0.2 & 95.8 & 87.2 & 90.0 & 2.8 \\
\hline Romania ${ }^{6)}$ & 1512 & 13.7 & 96.0 & 78.2 & 77.1 & -1.1 \\
\hline Slovakia ${ }^{7)}$ & 15378 & 6.2 & 98.1 & 63.6 & 74.4 & 10.8 \\
\hline Slovenia ${ }^{8)}$ & 15270 & 2.2 & 93.5 & 74.4 & 83.2 & 8.8 \\
\hline
\end{tabular}

*)Net survival

1) Estonia 2000-2012, ${ }^{2)}$ Spain 2000-2013, ${ }^{3)}$ Ireland 2000-2013, 4) Lithuania 2000-2012, 5) Malta 2000-2013, ${ }^{6}$ Romania 2006-2012, ${ }^{7)}$ Slovakia 2000-2010, ${ }^{8}$ Slovenia 2000-2013

In years $2010-2014$ the survival rose in every country and region across Europe, however, the changes were insufficient to level the differences in Europe; the survival was $93.6 \%$ in France and 54.8\% in Bulgaria. In Poland the survival in that period ranged from $72.3 \%$ (Opolskie voivodship) to $83.6 \%$ in Pomorskie voivodship. In Europe the lowest survival was in Bulgaria and some voivodships in Poland. However, in Pomorskie, Mazowieckie, Podlaskie, Lubuskie, Zachodniopomorskie, Śląskie voivodships the survival was within the European range (Figure 2).

\section{DISCUSSION}

In years 2000 - 2014 favourable changes in Poland resulted in a higher 5-year survival in prostate cancer patients. However, the changes varied to some extent, and consequently, the differentiation between voivodships remained. The greatest changes were in Lubuskie and Podlaskie voivodships (19 and 23 percentage points respectively), the lowest changes in Kujawsko-Pomorskie and Mazowieckie voivodships (Table 1).

Based on the World Health Organisation data, Wong et al. [24] and Bray et al. [6] performed the analysis of prostate cancer incidence rate and mortality rate trends in more than 30 countries worldwide in years $1998-2012$. It showed that in the majority of countries, including Poland, incidence rose and mortality decreases in that period.

In years 2012 and 2013 the mortality trend in Poland changed and became a rising one, with mortality incidence growing. In that period the 5-year survival also rose [10, 11, 19].

According to Wojtyniak et al. [23] there was a rise in mortality in 13 voivodships in Poland in years 2015 - 2016 in comparison to years $2000-2001$, whereas in 3 voivodships: Wielkopolskie, Kujawsko-Pomorskie and Pomorskie the trend was opposite - mortality decreased. The rising mortality trend is connected with demographic changes in Europe and Poland. Due to the aging society the number of men above the age of 45 was higher in years 2010 - 2014 than in years $2000-2004$ [16]. Moreover, early prostate cancer detection with the PSA test and prostate ultrasound became more available resulting in more prostate cancer patients referred to follow-up care and treatment.

Effective treatment depends on medical staff employment, adequate healthcare financing and effective organisation.

That epidemiological trend in Poland overlapped with unfavourable conditions for patients beginning cancer treatment. According to OECD) [17] the number of medicine doctors in Poland in year 2016 was the lowest in comparison to other European countries - 2.4 per 1000 inhabitants. The European average was 3.6 per 1000 inhabitants, whereas in Poland that number had not changed since year 2000, while the number of doctors in other European countries systematically rose [17]. Nurse employment in Poland was one of the lowest in Europe - 5.2 per 1000 inhabitants while the European average was 8.4 per 1000 inhabitants, reaching 16.2 in Denmark and 14.3 in Finland.

The data presented in Surveillance, Epidemiology and End Results Program, USA (SEER) [12] shows that among 332075 prostate cases diagnosed in years 2010 - 2016 in the United States 76\% was local stage prostate cancer. The 5-year survival for those patients was $100 \%$. In France in years 2010 - 2014 the 5-year survival was also very high -93.6 percentage points (Table 2). It suggests favourable diagnostic procedures in both countries, while an increased number of patients referred to further treatment after early diagnosis did not contribute to healthcare system burden. 
Bulliard and Chiolero [7] suggest that large-scale prevention, e.g. intensive early diagnosis, including prostate cancer, or population screenings lead to overdiagnosis, and consequently, the fast rise in patients referred to further diagnosis may lead to overtreatment. That may result in healthcare system burden and unfavourably influence the healthcare system quality - the impact is put on detection of no or little prostate cancer progression cases. The more serious cases may not be sufficiently diagnosed [7]. There has been a rise in the 5-year survival in Poland, which is the result of cancer prevention. At the same time, however, mortality rises, which may result from an insufficient healthcare system, for example longer waiting time for critically ill patients, lower treatment quality, complications and inadequately treated accompanying diseases.

The Polish Supreme Audit Office (NIK) data [22] shows that cancer care treatment in Poland faces a great number of obstacles, including the healthcare system ones. The most crucial problems in years 2000 -2014 were:

1. low cancer care financing (42 EUR per person in year 2014, whereas 85 EUR in the Czech Republic and 156 EUR in France [3],

2. improper cancer care network (in year 2012 oncological procedures were performed by 806 hospitals). However, the number of patients differed between hospitals $-80 \%$ of cancer patients was treated in about $10 \%$ out of 806 hospitals [9],

3. understaffing, particularly of pathomorphologists and nurses.

Moreover, according to NIK report 2018, in comparison to Western Europe Polish patients were provided with less access to modern technology, including innovative medicines $(53 \%$ out of 94 new cancer care medicines registered in the EU were unavailable in Poland). It may have been the consequence of excessively long registration process of new technologies in guaranteed medical services, which was confirmed by the Supreme Audit Office report [22].

The National Cancer Registry prognoses in Poland a rise in cancer incidence in men by $13.9 \%$ (up to 91 999 cases) and by $25.1 \%$ in women (up to 84200 cases) until year 2025 in comparison to year 2014 [8]. The prognosis related to prostate cancer incidence is 22 344 men in year 2025 in comparison to 12162 in year 2013 - that would be a double rise in incidence [8].

For years 2016 - 2024 was passed by the Polish Parliament in year 2015 a next National Cancer Programme (NCP) $[13,14]$. Its main objective was to decrease the distance to European indicators in the 5-year survival in cancer patients diagnosed with cancers responsible for the most deaths in Poland. The specific objectives included, among others, reducing the rise in cancer incidence (primary prevention), improving early detection (secondary prevention), providing access to effective treatment methods.

In year 2015 to facilitate cancer treatment by making diagnostics faster and waiting time shorter so called 'Oncological Package' with DiLO card (the Diagnosis and Oncological Treatment card) was introduced [14, 21]. The Package also regulated the cancer patient follow-up and the procedures of coming back to the primary healthcare after cancer treatment.

In order to improve cancer care in Poland much more, the National Oncology Network (NON) has been introduced. Its pilot programme for cancer care beneficiaries was launched by the regulation of the Ministry of Health of 13 December, 2018 in Dolnośląskie and Kieleckie voivodships and started a reorganisation process of cancer care into a modern structure [20]. The pilot programme includes breast, colon, lungs, prostate and ovarian cancers, and is gradually including the remaining voivodships.

Polish NON concept is complementary to the European concept of Comprehensive Cancer Care Network (CCCN). Organising $\mathrm{CCCN}$ is an answer to a more and more frequent need by cancer service providers for a comprehensive cooperation between cancer care centers based on reference guidelines outlined according to the competences of each centre and in agreement with the nowadays experts' opinions. A multidisciplinary comprehensive cooperation between cancer centres in the frame of the $\mathrm{CCCN}$ and evidence-based public health would greatly facilitate diagnosis and treatment and would reduce disparities in the access to high quality cancer services in a way required by experts. The definition of tumor specific CCCN and its crucial elements has been developed within the European project CanCon [2], and as a next step, implemented during JA iPAAC (innovative Partnership in Action Against Cancer Joint Action) [15]

A modern model of multidisciplinary cancer care organised in a cancer care network on different levels of reference allows for implementation of optimal cancer care pathway, from diagnosis to rehabilitation and palliative care. The cancer care quality is monitored with the use of indicators set for the need of standardised and comparable indicators in order to evaluate the key stages of cancer care performed within the Polish NON .

Currently, health expenditure on cancer care amounts to less than $6 \%$ of all expenditures on healthcare in Poland. Thus, it is necessary to increase health expenditure on cancer care in Poland, and consequently arrive, at least, at the European Union average. As a result, the National Cancer Plan for Poland was proposed in order to increase changes to 
enhance cancer care. The Strategy is included in the Act of Parliament of 24 April 2019 [1].

The ultimate goal for health care system financing is to increase health expenditure on cancer care to $7 \%$. The National Cancer Plan plans to increase expenditure for implementation of the actions as follows:

- in year 2020 not less than 250.3 million PLN;

- in 2011 - 2023 not less than 451.2 million PLN per year;

- in $2024-2030$ not less than 501.5 million PLN per year.

The expenditure would cover the following: investment in medical staff; - investment in education - primary prevention (lifestyle); investment in patients - secondary prevention; investment in science and innovations; investment in cancer care system.

Actions which will be taken within the National Cancer Plan aim at reversing unfavourable epidemiological trends, including rising mortality in prostate cancer. That should contribute to an increase of the 5-year population survival, which in case of many cancers in Poland significantly differs from the majority of European countries.

\section{CONCLUSIONS}

1. The 5-year survival in prostate cancer patients in years 2010 - 2014 in Poland was significantly lower in comparison to Western Europe countries, and favourable trends on a regional level in Poland were too slow to overcome high differentiation in Europe.

2. It is expected that changing the structure and organisation of cancer care in Poland into a modern National Oncology Network, together with the use of the experiences from European projects, including iPAAC and better financing will contribute to improvement in prostate cancer treatment in Poland.

\section{Acknowledgments}

This work was supported by statutory financial help of the National Institute of Public Health - National Institute of Hygiene in Warsaw, project No Zp-1 and Zp-1/2020 (ZO-2/2020).

\section{Conflict of interest}

The authors declare no conflict of interest.

\section{REFERENCES}

3. Act of 26 April 2019 r. National Oncological Strategy Dz. U. 2019 item 969 [Ustawa z dnia 26 kwietnia 2019 r. o Narodowej Strategii Onkologicznej. Dz. U 2019, poz. 969) (in Polish).
4. Albreht T, Kiasuwa, R., Van Den Bulcke, M.: European Guide on Quality Improvement in Comprehensive Cancer Control (Eds) (2017 r.)

5. All. Can: Increasing effectiveness and stability of oncological care. Recommendations for Poland (Poprawa efektywności i stabilności opieki onkologicznej. Rekomendacje dla Polski). Raport Inicjatywy All.Can, ed. K. Colombani, RPP Group, 2017

6. Allemani C, Weir H, Carreira H, Harewood R, Spika $D$, Wang X, Bannon F, Ahn J, Johnson Ch, Bonaventure $A$, Marcos-Gragera $R$, Stiller Ch, Azevedo e Silva $G$, Wan-Qing Chen, Ogunbiyi O, Rachet B, Soeberg M, You H,Matsuda T, Bielska-Lasota M, Storm H,Tucker T, Coleman M, CONCORD Working Group: Global surveillance of cancer survival 1995-2009: analysis of individual data for 25676887 patients from 279 population-based registries in 67 countries (CONCORD-2), Lancet 2015;385(9972): 977 - 1010

7. Allemani C, Matsuda T, Di Carlo V, Harewood R, Matz $M$, Nikšić $M$, Bonaventure A, Valkov M, Johnson Ch, Estève J, Ogunbiyi O, Azevedo e Silva G, Wan-Qing Chen, Eser S, Engholm G, Stiller Ch, Monnereau A, Woods R, Visser O, Gek Hsiang Lim, Aitken J,Weir H, Coleman M, CONCORD Working Group: Global surveillance of trends in cancer survival 2000-14 (CONCORD-3): analysis of individual records for 37 513025 patients diagnosed with one of 18 cancers from 322 population-based registries in 71 countries: Lancet 2018;391(10125):1023-1075.

8. Bray F, Lortet-Tieulent J, Ferlay J, Forman D, Auvinen $A$ : Prostate cancer incidence and mortality trends in 37 European countries: an overview. Eur.J Cancer 2010, 46: 3040 - 3052.

9. Bulliard, J., Chiolero, A. Screening and overdiagnosis: public health implications. Public Health Rev 2015;36:8. https://doi.org/10.1186/s40985-015-0012-1

10. Didkowska J, Wojciechowska U, Zatoński W: Prediction of cancer incidence and mortality in Poland up to the year 2025 (Prognozy zachorowalności i umieralności na nowotwory złośliwe w Polsce do roku 2025), http:// onkologia.org.pl/wp-content/uploads/Prognozy_2025. pdf : 2009 : 69-74, access 07.07.2020

11. Health need maps (Mapy potrzeb zdrowotnych) https:// basiw.mz.gov.pl/index.html\#/visualization?id=3404, access 08.09 .2020

12.https://gco.iarc.fr/today/data/factsheets/populations /616-poland-fact-sheets.pdf, access 10.09.2020

13. https://gco.iarc.fr/today/fact-sheets-populations, access 10.09.2020

14.https://seer.cancer.gov/csr/1975_2017/browse_csr.php ?sectionSEL $=23 \&$ pageSEL $=$ sect_23_table.08 access 06.08.2020

15.https://www.infor.pl/akt-prawny/MPO. 2015.210.0001165, uchwala-nr-208-rady-ministrow-wsprawie-ustanowienia-programu-wieloletniego-na-lata20162024-pod-nazwa-narodowy-program-zwalczaniachorob-nowotworowych.html [access 3.11.2020] Uchwała Nr 208 Rady Ministrów z dnia 3 listopada $2015 \mathrm{r}$. w sprawie ustanowienia programu wieloletniego 
na lata 2016-2024 pod nazwą „Narodowy Program Zwalczania Chorób Nowotworowych"

16. https://www.iccp-portal.org/plans/national-oncologystrategy-poland-2020-2030, access 20.10.2020

17. https://www.ipaac.eu/, access 1-10.08.2020

18. https://www.onkologia.org.pl/k/epidemiologia , access $1-15.06 .2020$

19. https://doi.org/10.1787/health_glance_eur-2018-en OECD/EU (2018), Health at a Glance: Europe 2018: State of Health in the EU Cycle, OECD Publishing, Paris access $2-15.05 .2020$

20.Jensen OM, Parkin DM, MacLennan R, Muir CS, Skeet $R G$, eds.Cancer registration: principles and methods (IARC Scientific Publications no. 95). Lyon: International Agency for Research on Cancer, 1991.

21. Kwiatkowska K, Zielińska A, Gliniewicz A, DudekGodeau D, Bielska-Lasota M: Curability of cancer in Poland - 5-year survival rate in 2000-2014. Differences between the country's regions (Wyleczalność chorych na nowotwory złośliwe w Polsce - wskaźnik 5-letnich przeżyć w latach 2000 - 2014. Zróżnicowanie między województwami) in: Health status of Polish population and its determinants (Sytuacja zdrowotna Polski i jej uwarunkowania), ed. Wojtyniak B, Goryński P, NIZPPZH Warszawa 2018;215 - 230

22.Regulation of Minister of Health, 21.06.2017, about diagnostic card template and oncological treatment (rozporządzenie Ministra Zdrowia w sprawie wzoru karty diagnostyki I leczenia onkologicznego), Official Journal of the Republic of Poland, Dz. U. 2017, item 1250.

23. Regulation of Minister of Health, 13.12.2018, about pilot programme of comprehensive patient care in oncological network (rozporządzenie Ministra Zdrowia w sprawie program pilotażowego opieki nad świadczeniobiorcą w ramach sieci onkologicznej), Official Journal of the Republic of Poland. Dz. U. 2018, item 2423. https://eli. gov.pl/api/acts/DU/2018/2423/text/I/D20182423.pdf

24. Report of Supreme Audit Office (Najwyższa Izba Kontroli) 2018: https://www.nik.gov.pl/plik/ id,16371,vp,18897.pdf, access 10.05.2020

25. Wojtyniak B, Stokwiszewski J, Rubikowska B, Goryński $P$, Zdrojewski T: Life longevity and mortality of Polish population (Długość życia i umieralność ludności Polski) in: Health status of Polish population and its determinants, ed. Wojtyniak B, Goryński P, NIZP-PZH Warszawa 2018:59 - 184

26. Wong M, Goggins W, Wang H, Fung F, Leung C, Wong $S$, Chi Fai Ng, Sung J: Global incidence and mortality for prostatę cancer: Analysis of Temporal Patterns and trends in 36 countries. Eur Urology 2016;70:862 - 874

Received: 29.10 .2020

Accepted: 04.12.2020 